\title{
Behavioral Insights in Public Policy: Ukrainian Case
}

\section{Svitlana Khadzhyradieva, Tetiana Hrechko, Anatolii Savkov}

\author{
National Academy for Public Administration under the President of Ukraine \\ 03057 Kyiv, Ezhena Pottier st. 20, Ukraine \\ cross $^{\text {ref }}$ http://dx.doi.org/10.5755/j01.ppaa.18.1.23130
}

\begin{abstract}
The OECD has identified 196 teams within governments across the world, designed with the purpose of using behavioral insights to improve national administrations. Citizens of various societies support nudges and nudging. However, the determinants of the nudge approval level have not been studied so far. It is not known why some types of nudges are approved by citizens of different countries to a greater extent, and others are actively disapproved. The aim of this study is to reveal the approval level of using Behavioral insights in Public Policy. We have formulated the nudge approval determinants, have analyzed the influence of nudge approval determinants on nudge approval level in 15 countries. We report the results of nationally representative survey of nudge approval level in Ukraine. We have found governance, cultural and experience determinants of nudge approval.
\end{abstract}

Keywords: Nudge, governance, culture, Hofstede cultural dimensions, Inglehart-Welzel Cultural Map, Ukraine.

Raktažodžiai: postūmis/ pokytis, valdymas, kultūra, Hofstede kultūrinès dimensijos, Inglehart - Welzel kultūros žemèlapis, Ukraina.

\section{Introduction}

We are in a Golden Age of behavioral science. Like never before, governments, NGOs, business entities, medical and law practitioners, as well as everyday citizens are paying appreciative attention to the thinking and research of behavioral scientists (Sunstein, Reisch, \& Rauber, 2018).

One of the reasons for the increased attention to behavioral sciences was the cognitive revolution, which resulted in the emergence of a field of interdisciplinary research. J. Miller (1920-2012), one of the founders of cognitive science, together with his colleagues identified six main disciplines, the development of which initially formed its basis: 1) Experimental cognitive psychology; 2) Philosophy of mind; 3) Neuroscience; 4) Cognitive anthropology; 5) Linguistics; 6) Computer science and artificial intelligence (Miller, 2003). 
Currently, cognitive science is a field of interdisciplinary cognition research, understood as a set of processes of acquisition, storage, transformation and usage of knowledge by living and artificial systems. (Falikman, 2012). One of the practical "outputs" of the studies, which are conducted within the framework of the cognitive hexagon, is a behavioral one, as the identified patterns allow to explain the specifics of decision-making and behavior of an individual as an element of systems of different nature: social, political, economic.

Whereas previously cognitive studies, based on a computer metaphor of the brain function, were paradigmatically opposed to classical behavioral ones, now they are naturally synthesized. The main vector in the development of modern cognitive science can be considered its return from the abstract "information processing system" back to a human being, a creature endowed with a physical body with certain anatomical and physiological features, having certain needs, experiencing emotions and, to top it all, included in a society and being in continuous interaction with other people as well as developing in this interaction (Falikman, 2012). As a result of this approach, the cognitive component broadens the range of understanding behavioral patterns, thus becoming a theoretical basis for behavior and decision making research.

A World Bank Group Flagship Report "Mind, Society, and Behavior" (2015) determines three principles of human decision making: thinking automatically, thinking socially, and thinking with mental models. These principles underlie the behavior of a human as a participant of social interactions, and each of these principles is axiomatically determined by the statements formulated within the framework of the cognitive hexagon.

Neuro-cognitive revolution contributed to updating the knowledge about the brain, having presented a number of fundamental provisions regarding the behavior of an individual as an element of a social system, which transformed the axiomatics of some social sciences. It became clear that the human brain is a partly outdated survival tool kit and there are limitations on its capacity. Our social and physical environments have changed considerably and evolution has not had time to reshape our bodies and minds, so we are sometimes left with behavioral tendencies that no longer always make rational sense. Thus our Biases Reflect Human Ecological Rationality (Boutang, De Lara, 2016). The influence of these specifics of cognitive processes on behavior is important for those sciences where the object of study is either an individual or the systems where he/she is an element.

Currently, along with further research within the framework of the cognitive hexagon, there is a diffusion of new knowledge into such sciences as: management, marketing, economics, political science, law, governance, design and engineering. For example, the field of Behavioural Economics is situated in a larger landscape of social and behavioral sciences, including cognitive and social psychology, and developments in the domain of neuroscience have opened up promising avenues for Behavioural Economics informed by better understanding of the human brain (Camerer, Loewenstein, Prelec, 2005).

With regard to governance, behavioral tools including a cognitive component are 
becoming an important part of state regulation practice.

The OECD has identified 196 teams within governments across the world, designed with the purpose of using behavioral insights to improve national administrations. Many large corporations around the world are starting to employ dedicated behavioral science teams, in order to change the behaviors of their customers and employees (Samson, 2018).

In some cases, they achieve high efficiency of the implemented activities which is regularly reflected in the BIT reports (Behavioural Insights Team). The conceptual basis for the functioning of behavioral teams at governance level is libertarian paternalism, and the methodological basis is sets of nudges or choice architecture tools. The level of social approval of the implemented activities is a debatable issue at implementing nudges. For democratic countries, this issue is an indicator of trust in the government and has political implications, and for hybrid and authoritarian regimes it becomes ethical.

Evidence about people's views cannot resolve the ethical questions, but in democratic societies (and probably nondemocratic ones as well), those views will inevitably affect what governments are willing to do (Sunstein, 2018).

The aim of this study is to reveal the approval level of using Behavioral insights in Public Policy. The objectives of this study are: 1) to reveal the nudge approval determinants, 2) to analyze the influence of nudge approval determinants on nudge approval level in different countries, 3) to investigate the nudge approval level of Ukrainian citizens.

\section{Theoretical framework}

Nudge approval determinants. The reasons for approval / disapproval of nudges at the individual level are outlined in the work Cass R. Sunstein Human Agency and Behavioral Economics Nudging Fast and Slow (2018). People are most likely to oppose those nudges, whether educative or not, that (1) promote what they see as illicit goals or (2) are perceived as inconsistent with either the interests or values of most choosers. A third source of opposition, one that counts against some default rules, is that people do not want choice architects to produce economic or other losses by using people's inertia or inattention against them. As we shall see, these are the three principal grounds on which people reject particular nudges. When nudges promote legitimate goals, are consistent with people's interests and values, and do not impose losses, it is highly likely that strong majorities will support them.

As for the collective approval of the nudge policy, now a global research consists of gathering facts and analyzing the nudge support in different countries. The reasons for the differences between the countries are left aside, being an object of discussion. At the same time, trust in the government (Hungary) and cultural specifics (China, South Korea) are mentioned as the main determinants of the nudge approval level in the course of the discussion. However, this approach does not have sufficient explanatory potential.

In this context, we can offer the following analytical model of the nudge 
approval (Fig. 1).

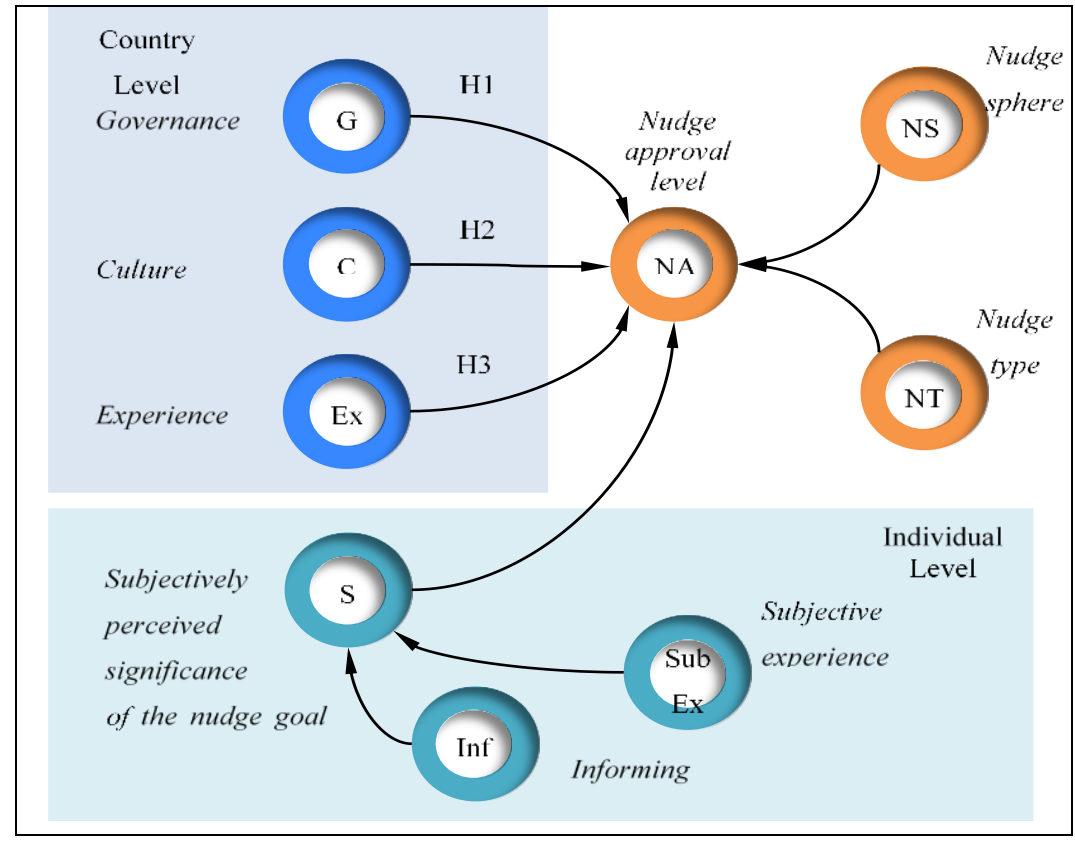

Fig. 1. Theoretical framework. Nudge approval determinants Source: formed by authors.

Nudge approval level is the support level of nudge activities in a social system under consideration (in this case, at the state level) used by choice architects that alters people's behavior in a predictable way without forbidding any options or significantly changing their economic incentives (Thaler, Sunstein, 2008). The nudges at the first detail level can be differentiated: by sphere of implementation (health care, economy, ecology, etc.) and by nudge type (informing, default rule, government regulation). Both the nudge sphere and the nudge type can affect the approval level for each particular nudge.

Further, it is advisable to single out collective determinants of the nudge approval level, to which, within the framework of the proposed model, the efficiency level of the governance system, cultural specifics of the social system and the experience of the social system are attributed.

And individual determinants, the main of which is the subjectively perceived significance of the nudge goal and legitimacy of means to achieve it. This parameter can be affected by many factors. Herein we have singled out two factors from the potential ones: the subject's experience, which determines the subjective significance of the nudge goal and the nature of its awareness of the extent of the problem that is proposed to be solved. These factors were determined based on the assumption about the dynamic nature of the nudge approval level both at the level of a social system and at the level of a particular subject. 
There are studies that focus on the search for typological, fairly stable features on an individual level that determine nudge patterns. For example, it has been argued that the people with dominating rational thinking are more inclined to approve System 2 nudges, and the people who are primarily guided by emotions and intuition will approve System 1 nudges (Hagman, et. al., 2015).

We believe that a typology can determine the reaction of various types of people to certain types of nudges, characterize their behavioral patterns to a greater extent, and it can determine the level of their approval of the nudge policy to a lesser extent. At the same time, if the citizens are informed about the extent of the existing problems in a given area beforehand, it can affect both the level of nudge approval in general, and the choice of a nudge type. After all, in order to be sufficiently effective, the means used must be adequate to the extent of the problem.

The proposed model is open and, in the framework of this study, it involves testing three hypotheses regarding the collective level of impact on the level of nudge approval:

H1: The state of governance is related to level of nudge approval.

$H 2$ : The characteristics of the culture of a social system are related to level of nudge approval.

H3: The previous experience of a social system is related to level of nudge approval.

The state of a governance system. To substantiate the first hypothesis, we shall consider World Governance Indicators (WGI) - six indicators reflecting the characteristics of a governance system. Based on a long-standing research program of the World Bank, the Worldwide Governance Indicators capture six key dimensions of governance. They measure the quality of governance in over 200 countries, based on close to 40 data sources produced by over 30 organizations worldwide and are updated annually since 2002. For each of the six dimensions of the quality of governance, a rating is given - from 0 to 100 . The lower the rating by a dimension is, the worse the quality of governance is.

The existing data related to nudge approval for 15 countries (Sunstein, Reisch, \& Rauber, 2018) show the correlation with the Worldwide Governance Indicators (Table 1). The calculation was performed using SPSS.

As Table 2 shows:

- 11 nudges out of 15 show a negative correlation with all World Governance Indicators;

- 4 types of nudges, such as: n3 - Information campaigns against smoking and overeating, n7 - Encouragement: Green energy, n8 - Mandate: Green energy, n10 - Red cross donation negatively correlate with all World Governance Indicators;

- 4 types of nudges do not correlate with the components of the governance effectiveness. These include: $\mathrm{n} 4$ - Calorie labels, n9 - Carbon emissions charge, n12 - Organ donor choice and n14 - Sweet-free cashier zones. 


\section{Table 1. Correlation between 15 nudges' approval level and the World Governance Indicators (WGI) for 15 countries $(\mathrm{N}=15)$}

\begin{tabular}{|c|c|c|c|c|c|c|}
\hline \multirow{2}{*}{ Spearman's rho } & \multicolumn{6}{|c|}{ World Governance Indicators (WGI) } \\
\hline & VA & PS & GoE & RQ & RL & $\mathrm{CC}$ \\
\hline Average Nudge &,- 508 &,$- 684^{* *}$ &,$- 722^{* *}$ &,- 492 &,$- 618^{*}$ &,$- 625^{*}$ \\
\hline Nudge 1 &,- 377 &,$- 582^{*}$ &,$- 566^{*}$ &,- 410 &,$- 555^{*}$ &,$- 539^{*}$ \\
\hline Nudge 2 &,- 452 &,- 481 &,$- 522^{*}$ &,- 396 &,- 486 &,- 500 \\
\hline Nudge 3 &,$- 526^{*}$ &,$- 667^{* *}$ &,$- 707^{* *}$ &,$- 528^{*}$ &,$- 653^{* *}$ &,$- 633^{*}$ \\
\hline Nudge 4 &,- 400 &,- 347 &,- 424 &,- 262 &,- 373 &,- 438 \\
\hline Nudge 5 &,- 457 &,$- 662^{* *}$ &,$- 612^{*}$ &,- 443 &,$- 536^{*}$ &,$- 547^{*}$ \\
\hline Nudge 6 &,- 492 &,$- 770^{* *}$ &,$- 672^{* *}$ &,- 477 &,$- 613^{*}$ &,$- 556^{*}$ \\
\hline Nudge 7 &,$- 743^{* *}$ &,$- 587^{*}$ &,$- 709^{* *}$ &,$- 710^{* *}$ &,$- 770^{* *}$ &,$- 777^{* *}$ \\
\hline Nudge 8 &,$- 605^{*}$ &,$- 637^{*}$ &,$- 668^{* * *}$ &,$- 577^{*}$ &,$- 697^{* *}$ &,$- 693^{* *}$ \\
\hline Nudge 9 &,- 131 &,- 134 &,- 186 &,- 005 &,- 107 &,- 091 \\
\hline Nudge 10 &,$- 786^{* *}$ &,$- 536^{*}$ &,$- 804^{* *}$ &,$- 732^{* *}$ &,$- 796^{* *}$ &,$- 825^{* *}$ \\
\hline Nudge 11 &,- 427 &,$- 772^{* *}$ &,$- 692^{* *}$ &,$- 538^{*}$ &,$- 627^{*}$ &,$- 624^{*}$ \\
\hline Nudge 12 & ,371 &, 014 & ,047 & ,331 & ,294 &, 217 \\
\hline Nudge 13 &,- 466 &,- 484 &,$- 595^{*}$ &,- 395 &,$- 527^{*}$ &,- 504 \\
\hline Nudge 14 &, 218 &,- 220 &, 031 & ,286 &, 187 &, 180 \\
\hline Nudge 15 &,- 370 &,$- 686^{* *}$ &,$- 606^{*}$ &,- 439 &,$- 573^{*}$ &,- 529 \\
\hline \multicolumn{7}{|l|}{ Notes: } \\
\hline \multicolumn{7}{|c|}{$* *$ Correlation is significant at the 0,01 level (2-tailed). } \\
\hline \multicolumn{7}{|c|}{ * Correlation is significant at the 0,05 level (2-tailed). } \\
\hline \multicolumn{7}{|c|}{$\begin{array}{l}\text { Nudges: } 1 \text { - Childhood obesity, } 2 \text { - Distracted driving, } 3 \text { - Information campaigns against smoking and overeating, } 4 \text { - } \\
\text { Calorie labels, } 5 \text { - High levels of salt, } 6 \text { - Traffic lights, } 7 \text { - Encouragement: Green energy, } 8 \text { - Mandate: Green } \\
\text { energy, n9 - Carbon emissions charge, } 10 \text { - Red cross donation, } 11 \text { - Healthy food placement, } 12 \text { - Organ donor } \\
\text { choice, } 13 \text { - Subliminal advertisements , } 14 \text { - Sweet-free cashier zones, } 15 \text { - Meat-free day in public canteens. }\end{array}$} \\
\hline \multicolumn{7}{|c|}{$\begin{array}{l}\text { World Governance Indicators: VA - Voice \& Accountability, PS - Political Stability and Lack of Violence, GoE - } \\
\text { Government Effectiveness, RQ - Regulatory Quality, RL - Rule of Law, CC - Control of Corruption. }\end{array}$} \\
\hline
\end{tabular}

\section{Source: formed by authors.}

The most correlated World Governance Indicators are PS - Political Stability and Lack of Violence и GoE - Government Effectiveness, the least correlated are VA Voice \& Accountability, RQ - Regulatory Quality. This can be explained by the fact that, in a state of political instability, a nudge is perceived by citizens as a way to meet the need for more effective governance and leads to a high level of approval. In addition, the reason for the negative correlation may be, to some extent, the quality of the chosen set of nudges for testing. According to Thaler "... People will need nudges for decisions that are difficult and rare, for which they do not get prompt feedback, and when they have trouble translating aspects of the situation into terms that they can easily understand" (Thaler, Sunstein, 2008). Does the selected test list include such types of nudges? It does, but they are not the majority. Among them there are no complex financial decisions like insurance plans and pension programs. However, 
there is a nudge to make a decision on organ donation. Nevertheless, based on the data obtained, it can be said that governance inefficiency contributes to the citizens' approval of both informing campaigns and the use of default rules.

Culture. The research findings of Sunstein C. R., Reisch L. A. \& Rauber J. (2018) say that most people have no views, either positive or negative, about nudging in general; their assessment turns on whether they approve of the purposes and effects of particular nudges. We shall see that there is some preliminary evidence on exactly that question, with valuable data from Sweden, and evidence that people in Denmark, France, Germany, Hungary, Italy, and the United Kingdom have broadly similar reactions to those of Americans. On the basis of that evidence, it is reasonable to think that people in diverse nations hold the same basic principles and that their divergences are relatively minor.

In this context, we can assume that, along with universal principles that determine the approval level of nudge activities, there are culturally conditioned factors that determine the differences in the support level for different countries. Cultural specifics are presented according to the model of Geert Hofstede (Hofstede, et. al., 2010). The Hofstede model of national culture consists of six dimensions. The cultural dimensions represent independent preferences for one state of affairs over another that distinguish countries (rather than individuals) from each other.

In addition to the model of Geert Hofstede, it is proposed to analyze the impact of the factors identified at the formation of Inglehart-Welzel Cultural Map (2017). This system stems from the World Values Survey (WVS), the largest noncommercial, cross-national, time series investigation of human beliefs and values ever executed, which dates to 1981 and includes nearly 400,000 respondents from 100 countries.

Table 2 shows the correlation dependencies calculated using SPSS between the support level of 15 types of nudges by the citizens of 15 countries and the cultural specifics of these countries. The correlation between the average level of nudges' approval and cultural dimensions was calculated separately.

As Table 2 shows:

- most types of nudges show a positive correlation with the power distance index PDI and / or demonstrates a negative correlation with the level of individualism IDV;

- $\quad$ two types of nudges negatively correlate with the indulgence level (IND). Among them are n7 - Encouragement: Green energy and n10 - Red cross donation;

- 4 types of nudges do not correlate with cultural specifics, such as: n6 Traffic lights, n9 - Carbon emissions charge, n14 - Sweet-free cashier zones, n15 - Meat-free day in public canteens;

- $\quad \mathrm{n} 12$ - Organ donor choice deserves special attention. Support for this type of nudge is characteristic of the social systems with a low level of longterm orientation and a high level of indulgence (in Hofstede system), with traditional values that are combined with self-expression values (in 
Inglehart-Welzel system).

\section{Table 2. Correlation between 15 nudges' approval level and the cultural dimensions for} 15 countries $(\mathbf{N}=\mathbf{1 5})$

\begin{tabular}{lcccccccc}
\hline \multirow{2}{*}{ Nudges } & \multicolumn{9}{c}{ Hofstede } & \multicolumn{3}{c}{ Inglehart-Welzel } \\
\cline { 2 - 9 } & PDI & IDV & MAS & UAI & LTO & IND & Ratio & Self \\
\hline Average Nudge &, $563^{*}$ &,- 490 &,- 141 &,- 013 &, 075 &,- 297 &,- 351 &,- 439 \\
\hline Nudge 1 &, 507 &,$- 526^{*}$ &,- 290 &, 153 &, 049 &,- 267 &,- 326 &,- 399 \\
\hline Nudge 2 &, $590^{*}$ &,- 474 &,- 245 &, 102 &, 074 &,- 217 &,- 289 &,- 377 \\
\hline Nudge 3 &, $642^{* *}$ &,$- 610^{*}$ &,- 169 &, 106 &, 236 &,- 413 &,- 251 &,- 507 \\
\hline Nudge 4 &, $532^{*}$ &,- 420 &,- 270 &, 027 &, 061 &,- 211 &,- 320 &,- 316 \\
\hline Nudge 5 &, $619^{*}$ &,$- 582^{*}$ &,- 344 &, 093 &, 192 &,- 302 &,- 228 &,- 431 \\
\hline Nudge 6 &, 478 &,- 485 &,- 097 &, 007 &, 275 &,- 419 &,- 186 &,- 498 \\
\hline Nudge 7 &, $594^{*}$ &,$- 553^{*}$ &, 050 &, 065 &, 151 &,$- 553^{*}$ &,- 246 &,$- 707 * *$ \\
\hline Nudge 8 &, $556^{*}$ &,$- 526^{*}$ &,- 050 &,- 011 &, 118 &,- 472 &,- 331 &,$- 576^{*}$ \\
\hline Nudge 9 &, 128 &,- 390 &, 025 &,- 302 &, 068 &, 057 &,- 124 &,- 093 \\
\hline Nudge 10 &, $760^{* *}$ &,$- 613^{*}$ &, 057 &, 275 &, 264 &,$- 561 *$ &,- 123 &,$- 729^{* *}$ \\
\hline Nudge 11 &, $574^{*}$ &,- 365 &,- 264 &, 091 &,- 029 &,- 283 &,- 436 &,- 372 \\
\hline Nudge 12 &,- 224 &, 434 &,- 187 &,- 439 &,$- 614^{*}$ &, $584^{*}$ &,$- 660^{* *}$ &, $616^{*}$ \\
\hline Nudge 13 &, 485 &,$- 529^{*}$ &, 045 &,- 009 &, 216 &,- 314 &,- 191 &,- 447 \\
\hline Nudge 14 &,- 172 &, 220 &,- 152 &,- 473 &,- 328 &, 444 &,- 297 &, 344 \\
\hline Nudge 15 &, 446 &,- 366 &, 011 &,- 110 &, 082 &,- 313 &,- 253 &,- 286 \\
\hline
\end{tabular}

Notes:

** Correlation is significant at the 0,01 level (2-tailed).

* Correlation is significant at the 0,05 level (2-tailed).

Nudges: n1 - Childhood obesity, n2 - Distracted driving, n3 - Smoking and overeating, n4 - Calorie labels, n5 High levels of salt, n6 - Traffic lights, n7 - Encouragement: Green energy, n8 - Mandate: Green energy, n9 Carbon emissions charge, n10 - Red cross, n11 - Healthy food placement, n12 - Organ donor choice, n13 Subliminal advertisements , n14 - Sweet-free cashier zones, n15 - Meat-free day in public canteens.

Hofstede cultural dimensions: PDI - power distance index, IDV - individualism versus collectivism, MAS masculinity versus femininity, UAI - uncertainty avoidance index, LTO - long term orientation versus short term normative orientation, IND - indulgence versus restraint;

Inglehart-Welzel cultural dimensions: Ratio - Traditional values versus Secular-rational values, Self - Survival values versus Self-expression values.

\section{Source: formed by authors.}

There is a reliable (significant at the $\alpha<0.05$ level) non-zero correlation between the average support level for the set of 15 types of nudges and a high power distance index. (PDI). People in societies exhibiting a large degree of Power Distance accept a hierarchical order in which everybody has a place and which needs no further justification. In societies with low Power Distance, people strive to equalize the distribution of power and demand justification for inequalities of power (Hofstede, G. et. al., 2010). Thus, when considering the nudge policy in the context of cultural specifics, libertarian paternalism is perceived primarily as paternalism. The countries 
that have gained the experience in such management presumably can become more susceptible to the differences in these sets of actions.

Previous experience. Positive or negative experience related to the policy of paternalism, hypothetically, can influence the level of support for certain types of nudges. Thus, the UK, which has a positive experience in active policy of libertarian paternalism, demonstrates a high level of support for the nudge policy. Russia and Hungary, the post-Soviet countries that have a negative experience in paternalism, demonstrate the opposite reaction, which is clearly illustrated by n15 - Meat-free day in public canteens. Modern evaluation of the previous experience is carried out in these countries taking into account the attitude to the historical past. ${ }^{1}$.

Hypotheses for Ukraine. Using the assessment data of correlation dependencies, we can formulate several assumptions regarding the expected level of support for nudge activities in Ukraine.

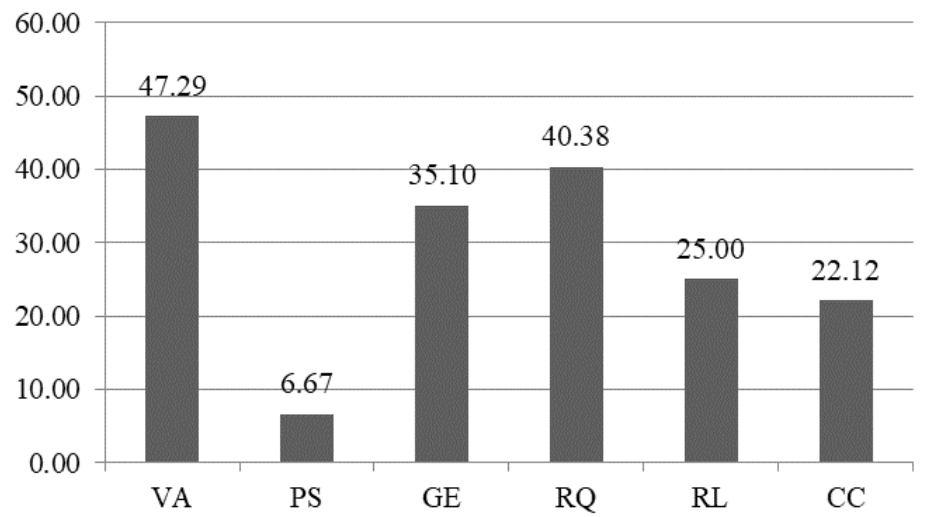

Fig. 2. Worldwide Governance Indicators, 2017. Ukraine

Notes: VA - Voice \& Accountability, PS - Political Stability and Lack of Violence, GoE - Government Effectiveness, RQ - Regulatory Quality, RL - Rule of Law, CC - Control of Corruption.

Source: https://resourcewatch.org/data/explore/soc029-Worldwide-Governance-Indicators.

Given the characteristics of Worldwide Governance Indicators (Fig. 2), it can be assumed that Ukrainian citizens will demonstrate a relatively high approval level of the government policy using nudge methods. As previously revealed, the approval of

\footnotetext{
1 In the Soviet Union, the introduction of a fish menu for the population was caused by a decline in meat production and the fight against a lack of protein in the diet. A. Mikoyan was the author of the "fish day" introduced on September 12, 1932 by the resolution of the People's Commissariat for Food Supplies of the USSR "On the introduction of the fish day at public canteens".

Later, on October 26, 1976, the Central Committee of the CPSU issued the second resolution on the introduction of the "fish day". This time, the reason for its introduction was not so much the lack of meat food, as the desire of the country's leadership to increase the fish production. A special day of the week, Thursday, was reserved for the fish day. On this day, many public canteens did not include any meat dishes in the menu, which caused discontent among workers and employees. The fact that the fish day was appointed on Thursday, of all days, was given a clear justification, backed up by statistics and calculations, which boil down to the fact that the sales of fish would be maximum on that day.
} 
the chosen nudge set negatively correlates with the governance level. The Hofstede's cultural dimensions define Ukraine as a country with a high level of power distance (92 points out of 100) and a rather low level of individualism (25 points). Such dimensions, as well as governance indicators, suggest a high support level of the presented set of nudge activities (Fig. 3).

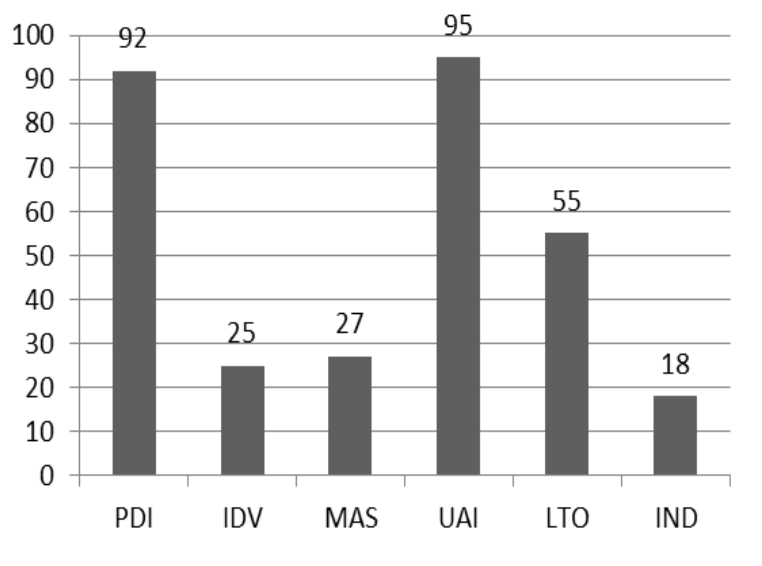

\section{Fig. 3. Hofstede dimensions of national culture, Ukraine}

Source: Hofstede - https://www.hofstede-insights.com.

In the coordinate system on Culture-Map Inglehart-Welzel, Ukraine is positioned as a country with prevailing survival values ( -1.45 points), but with dominating secular-rational values ( 0.51 points). This fact suggests a low level of approval of $n 12$ - Organ donor choice, the support of which requires predominating self-expression values with dominating traditional culture. An assumption can also be made about the lack of approval of $\mathrm{n} 15$ - Meat-free day in public canteens, due to previous experience of the social system.

\section{Experimental design}

To study the support level of the nudge policy in Ukraine, we used a questionnaire developed by Reisch \& Sunstein (2016) for conducting global research. To obtain results comparable to other European countries, the questionnaire was used unchanged. The questionnaire consists of 15 questions and offers two answer options: "Approve" and "Disapprove" a hypothetical version of state policy. The survey was performed with the support of Tilda.com. The questionnaire was translated and posted at: http://uanudge.tilda.ws/survey. A respondent could use any type of device to complete the questionnaire (PC, tablet, mobile phone). Data collection was carried out by posting the questionnaire on Facebook by three users. The research period was 3 months. Characteristics of the sample are presented in Table 3.

Coding and analysis were performed using SPSS. Approval rates were calculated per nudge. At the second detail level, the approval rates were calculated for the 
groups formed according to socio-demographic characteristics: level of education, income level, age and place of residence.

Table 3. Sample representativeness and methodology. Ukraine

\begin{tabular}{|l|l|}
\hline Sample size & 938 \\
\hline Population & $18+$ years (35 million), internet users \\
\hline Sampling error & Confidence level 95\%, Sampling error 3,2\%. \\
\hline Representativeness & Online representative for age, education, income, region \\
\hline Survey method & CAWI (Computer Assisted Web Interview) ad hoc \\
\hline Weighting method & No weighting \\
\hline Sample & Quota sampling \\
\hline Recruiting for the panel & Online \\
\hline Frame of the survey & Ad hoc, no other frames \\
\hline
\end{tabular}

Source: formed by authors according to the research results.

\section{Results}

The following support levels of the policy of libertarian paternalism in Ukraine were obtained from the survey (Fig. 4). Three kinds of nudges received low support level by Ukrainians (less than 30\%): n10 - Red cross, n12 - Organ donor choice, and $\mathrm{n} 15$ - Meat-free day in public canteens. The average value of the support level for the tested set of nudges is comparable to European countries; it is $66 \%$. Thus, the study of the nudge support in Ukraine substantiated the formulated hypotheses regarding various types of nudges.

n1 - Chil dhood obesity

$\mathrm{n} 2$ - Distracted driving

n3 - Smoking and overeating n4 - Calorie labels

n5 - High levels of salt n6 - Traffic lights

n7 - Encouragement: Green energy n8 - Mandate: Green energy n9 - Carbon emissions charge n10 - Red cross

n11 - Healthy food placement n12 - Organ donor choice n13 - Subliminal advertisements

n14 - Sweet-free cashier zones $\mathrm{n} 15$ - Meat-free day in public canteens

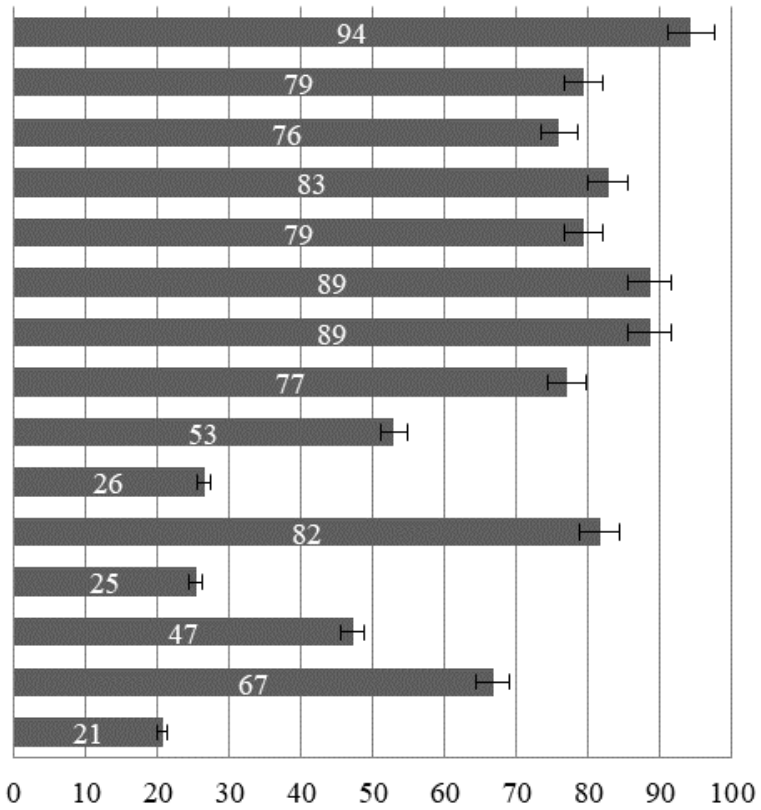

Fig. 4. Nudge approval level in Ukraine, $95 \%$-CI

Source: formed by authors according to the research results. 
H1: State of a governance system has an impact on the approval of nudge activities.

It is true for the average level of support for nudge activities. Ukraine, as a country with relatively low indicator values that negatively correlate with the support level for nudges, demonstrated the high level of support for 10 nudges out of 15 . High level of support was given to the nudge sets related to 1) governmental information campaigns; 2) mandatory information disclosure requirements imposed by governments. The support for mandatory subliminal advertising (n13) is also relatively high (47\% approval). This Non-nudge (in the classification of Lucia A. Reisch \& Cass R. Sunstein) negatively correlates with World Governance Indicators GoE - Government Effectiveness and RL - Rule of Law, as well as with the individualism level in Hofstede cultural model. Low rates of these indicators in Ukraine determined a relatively high level of support for subliminal advertising.

H2: Cultural characteristics of a social system determine the approval level for nudge activities.

The assumption about the low support level of n12 - Organ donor choice (25\% respondents) was substantiated due to the cultural specifics of the country, i.e. the prevalence of survival values and secular-rational values, as well as the low level of indulgence (IND) in the Hofstede cultural dimensions.

H3: Previous experience of a social system determines the approval level of nudge activities.

It is true for n15 - Meat-free day in public canteens. The Soviet past and the negative attitude towards it determined the negative attitude of Ukrainians towards this type of nudging. The social system is capable of self-learning. Therefore, the past experience can influence the approval level of nudge activities. Positively - like in the UK, and negatively - like in the countries of the former USSR, which is clearly seen from question 15. It should be noted that in Russia, where nostalgia for the Soviet period is a part of state policy (Back in USSR), the support of this question is higher than in Ukraine, a country with the opposite vector of state development.

The presented set of hypotheses does not fit into the low approval level of n10 Red cross donation by Ukrainians (only $26 \%$ of respondents). At the same time, the support of a similar nudge $\mathrm{n} 9$ - Carbon emissions charge is 53\%. This fact can be explained by the attitude of citizens to the donation amount. The quality of the forecasts using the model of nudge approval determinants (Fig. 1) can be improved as we obtain new data on the support level of nudge activities from other countries and recalculating correlation values.

\section{Conclusions}

1. The state of a governance system has an impact on the support level for the nudge policy. In the state of political instability and lack of effectiveness of governance, nudging is perceived by citizens as a way to meet the need for more efficient governance and causes a greater extent of approval. 
2. The cultural specifics of countries can influence the support level for nudge policy. When considering the nudge policy in the context of cultural specifics, libertarian paternalism is perceived primarily as paternalism. Presumably the countries that have gained experience in such management can become more susceptible to the differences in these sets of activities.

3. The past experience of a social system associated with the implementation of the nudge policy can influence the support level for similar activities in the present.

4. The state of a governance system, cultural specifics and past experience of a social system can be considered to be determinants of the approval level for sets of nudges. The revealed patterns are not imperative and require further study.

5. The study of the approval level for nudge activities in Ukraine showed the support at the level of European countries. The peculiarities of the Ukrainians' attitude to the tested set of nudge types is the low approval level (less than $30 \%$ ) of three types of nudges: n10 - Red cross, n12 - Organ donor choice, and n15 - Meatfree day in public canteens.

6. The nudge activities are a practical implementation of the "behavioral output" of cognitive science. Its further development will inevitably lead to a deeper diffusion of new knowledge in a number of social sciences. Therefore, the implementation of the choice architecture tools along the line "public policy strategy - a supporting set of nudging methods in the implementation process" is a direction given by evolution that significantly enriches the set of state regulation methods that are adequate to the essence of the management object

\section{Literatūra}

1. Boutang, J., \& De Lara, M. The Biased Mind. How Evolution Shaped Our Psychology Including Anecdotes and Tips for Making Sound Decisions. Switzerland: Springer International Publishing, 2016.

2. Camerer, C., Loewenstein, G., \& Prelec, D. Neuroeconomics: How Neuroscience Can Inform Economics. Journal of Economic Literature, 2005, 43, p. 9-64.

3. Falikman, M. V. Cognitive Science in the 21st Century: Body, Society, and Culture. PsyAnima, Dubna Psychological Journal, 2012, 3, p. 31-37. http://www.psyanima.ru/journal/2012/3/2012n3a2/2012n3a2.1.pdf.

4. Hagman, W., Andersson, D., Västfjäll, D., \& Tinghög, G. Public Views on Policies Involving Nudges. Public Views on Policies Involving Nudges. Review of Philosophy and Psychology, 2015, 6, p. 439-453.

5. Hofstede, G., Hofstede, G. J., \& Minkov M. Cultures and Organizations: Software of the Mind. McGraw-Hill, 2010.

6. Hofstede insights. Compare Countries. https://www.hofstede-insights.com.

7. Inglehart, R. Modernization and Postmodernization: Cultural, Economic, and Political Change in 43 Societies. Princeton, NJ: Princeton University Press, 1997.

8. Inglehart, R., \& W. E. Baker. Modernization, Cultural Change, and the Persistence of Traditional Values. American Sociological Review, 2000, 65, p. 9-51.

9. Inglehart-Welzel Cultural Map, 2017 
http://www.worldvaluessurvey.org/WVSContents.jsp.

10. Kahneman, D. Thinking, Fast and Slow. New York, NY: Farrar, Strauss, and Giroux, 2011.

11. Miller, A. G. The Cognitive Revolution: A Historical Perspective. TRENDS in Cognitive Sciences, 2003, 7(3), p. 141-144.

12. Mind, Society, and Behavior. International Bank for Reconstruction and Development / The World Bank, 2015.

13. Nudge and the Law. A European Perspective. Edited by Alberto Alemanno and AnneLise Sibony. Oxford and Portland, Oregon.

14. OECD, Greening Household Behaviour: The Role of Public Policy, OECD Publishing, 2011. http://dx.doi.org/10.1787/9789264096875-en.

15. OECD, Behavioural Insights and Public Policy: Lessons from Around the World, OECD Publishing, Paris, 2017. http://dx.doi.org/10.1787/9789264270480-en.

16. Peter, J. How Far to Nudge? Assessing Behavioural Public Policy. Edward Elgar Publishing Limited, 2018.

17. Samson, A. (Ed.). The Behavioral Economics Guide (with an Introduction by Robert Cialdini), 2018.

18. Sterbenz Christina. This Chart Explains Every Culture In The World. Business Insider, 2014, 3.

19. Sunstein C. R. The Ethics of Influence: Government in the Age of Behavioral Science. CUP, New York, 2016.

20. Sunstein, C. R. Human Agency and Behavioral Economics Nudging Fast and Slow. Palgrave Macmillan, 2018.

21. Sunstein, C. R., Reisch, L. A. Do Europeans Like Nudges? Judgment and Decision Making, 2016, 11(4), p. 310-325.

22. Sunstein, C.R., Reisch, L.A., \& Rauber, J. A Worldwide Consensus on Nudging? Not Quite, But Almost. Regulation \& Governance, 2018, 12, p. 3-22.

23. Thaler, R. H., Sunstein, C. R. Nudge: Improving Decisions About Health, Wealth, and Happiness. New Haven, CT: Yale University Press, 2008.

24. The Behavioral Foundations of Public Policy. Edited by Eldar Shafir. Princeton University Press. Princeton and Oxford, 2013.

25. The Behavioural Insights Team. Update Report 2016-2017. https://www.bi.team/publications/the-behavioural-insights-team-update-report-2016-17.

26. Weinschenk, S. Neuro Web Design: What Makes Them Click? Berkeley, CA: New Riders, 2009.

27. Zurawicki, L. Neuromarketing Exploring the Brain of the Consumer. Springer-Verlag Berlin Heidelberg, 2010. 
Svitlana Khadzhyradieva, Tetiana Hrechko, Anatolii Savkov

\section{EIgesio ịžvalgos viešojoje politikoje: Ukrainos atvejis}

Anotacija

EBPO nustatè, kad 196 vyriausybinès komandos pasaulyje naudoja su elgsena susijusias ižvalgas šalies administracijos gerinimui. İvairių visuomenių piliečiai palaiko pokyčius ir patị keitimo procesą. Tačiau veiksniai, nusakantys pritarimo pokyčiams mastą nèra išstudijuoti. Nèra žinoma, kodèl skirtingų šalių piliečiai vienus pokyčius palaiko, o kitiems aktyviai priešinasi. Šio tyrimo tikslas yra atskleisti pritarimo su elgesiu susijusioms ịžvalgoms viešojoje politikoje lygị. Tyrimo autoriai formuluoja pritarimo pokyčiams veiksnius, analizuoja pritarimo pokyčiams veiksnių itaką pritarimo mastui 15-oje pasaulio šalių, pateikia reprezentatyvaus pritarimo pokyčiams tyrimo Ukrainoje rezultatus, bei identifikuoja pritarimo pokyčiams valdymo, kultūrinius ir patirties veiksnius.

Khadzhyradieva Svitlana - Doctor of social sciencesciences, Chairman and associated professor in the Department of Public Administration and Public Service, National Academy of Public Administration under the President of Ukraine.

E-mail: sententia.hsk@gmail.com

Hrechko Tetiana - Doctor of social sciencesciences, associated professor in the Department of Public Administration and Public Service, National Academy of Public Administration under the President of Ukraine.

E-mail: grechkotatyana@gmail.com

Savkov Anatolii - Doctor of Science in Public Administration, Vice President of the National Academy for Public Administration under the President of Ukraine, Ukraine.

E-mail: anatolijsavkov2018@gmail.com

Khadzhyradieva Svitlana yra docentè, socialinių mokslų daktarè, Nacionalinès akademijos prie Ukrainos Respublikos prezidento Kijeve, Viešojo Administravimo ir Viešujų Paslaugų departamento pirmininkè.

E. paštas: sententia.hsk@gmail.com

Hrechko Tetiana yra socialinių mokslų daktarè, Nacionalinès akademijos prie Ukrainos Respublikos prezidento Kijeve, Viešojo Administravimo ir Viešuju Paslaugų departamento docent.

E. paštas: grechkotatyana@gmail.com

Savkov Anatolii yra viešojo administravimo mokslų daktaras, Nacionalinės viešojo administravimo akademijos prie Ukrainos Prezidento viceprezidentas.

E. paštas: anatolijsavkov2018@gmail.com

Straipsnis įteiktas redakcijai 2019 m. sausio mèn.; recenzuotas; parengtas spaudai 2019 $\mathrm{m}$. vasario mèn. 